\title{
FIELD PLACEMENT (EXTERNSHIP) - A VALUABLE APPLICATION OF CLINICAL EDUCATION?
}

\author{
GRAEME COSS*
}

"A child educated only at school is an uneducated child"

George Santayana, Why I Am Not a Marxist, Modern Monthly 9:77

The three primary models of clinical legal education can be readily distinguished. ${ }^{1}$

- In-house programs involve live-client contact as well as supervision by a full-time member of Faculty; the same program may also be situated off-campus.

- Simulation programs are free of live-client case work.

- Field placements (or externships) may have live-client work, but primary responsibility for supervision rests with persons other than full-time Faculty.

Externships permit more students the opportunity of having clinical experiences than do in-house clinics, ${ }^{2}$ where costs and the very nature of the educational experience place severe limitations on the numbers of students permitted to enroll. ${ }^{3}$ Externships have thus been hailed as the one form of clinical experience potentially available to all students. ${ }^{4}$

Their detractors however, are legion: "If there is a conventional wisdom about [externships], it is that schools that are serious about clinical education should not operate such programs. ${ }^{5}$ Although inhouse programs are invariably criticised for their high establishment and running costs, and simulation programs are viewed as "inferior" because of their want of intense dynamic 
exposure, ${ }^{6}$ externships are cursorily dismissed for the perceived dearth of a worthwhile educational experience. Lack of planning, lack of Faculty involvement and lack of adequate supervision are focussed on as the primary shortcomings of these "farm-out" programs, as they are derisively labeled. ${ }^{7}$ As has been recognised by more than one commentator:

[O]ne danger of out-of-house placements is that our students may be exposed to poor lawyering, that this behaviour might serve as a model for them, and that they might come away from the experience with serious misconceptions about their professional roles and work. To give credit for such an experience would be ludicrous. ${ }^{8}$

Possible solutions will be addressed later. Simply, there needs to be proper planning, Faculty involvement, and adequate supervision.

Amongst the professions, law schools have proved to be the tardiest innovators with respect to the integration of field placements into the standard curriculum. ${ }^{9}$ Medicine, ${ }^{10}$ dentistry, pharmacy, architecture, education, social work, psychology and ministry all stipulate field work as a mandatory component of their courses of study.

Law schools must seize a valuable opportunity in making use of an infrastructure that is already there, even if only in embryo form: ${ }^{11}$

[A] significant number of upper division students work substantial hours in various law clerking positions... . The question [is] if and how the law schools can restructure their educational programs so as to utilize the work experience as a meaningful learning experience... . A professional program that sees a majority of its students spending as much time in non-credit learning as in faculty approved learning suggests serious deficiencies with the curricular system of that profession. We need to look at what so attracts students to learn in the field, and then design ways to use it. ${ }^{12}$

Advantages stemming from the adoption of an astutely structured field placement program are numerous. ${ }^{13}$ The most comprehensive in-house programs still cannot accord students the range of clinical experiences feasible in externships. Placements can be very wide-ranging in the venues selected, ${ }^{14}$ and consequently in the scope of substantive specialization. ${ }^{15}$ An arguable limitation of in-house clinics is the lack of, or inappropriateness of, "government work", which may be a strong feature of an externship program.

Statistics from American law schools reveal that the majority of 
placements occur with non-profit law firms and public agencies. This has been saluted because "more law students [go] into public service positions early in their legal career - legitimizing and encouraging pro bono work, and providing needed support for under-financed and under-supported agencies and offices. Such placements de emphasize personal gain as the primary motivation for becoming a lawyer ..."16 To have students working with firms and agencies which have a public service vision, saves law schools the significant expenditure of establishing and operating such an office. Everyone may benefit from such a system. "Placement programs ... provide the opportunity to take advantage of existing community resources and design an educationally sound experience that encompasses the non-ideal conditions in which students will actually practice after graduation." ${ }^{17}$

\section{EDUCATIONAL VALUE}

Educators have long acknowledged the importance of realism in the learning process:

If an experience seems real, the beneficial effects on students are likely to be several. Students have more interest in the subject matter, and are better motivated to learn. They work harder, and pay closer attention to what is happening. They tend to learn things at a deeper level, and thus to remember them longer... . [F] eelings of concern about perceived injustice and misery are more easily aroused. ${ }^{18}$

Students faced with their client's predicament respond with enthusiastic energy; principles churned out in class are transformed by the dynamics into meaningful knowledge. Although one would certainly not suggest that placing a student in a work environment is the be all and end all of a legal education, ${ }^{19}$ nevertheless as one commentator has observed, "[r]eal world experience mutes the scepticism of many law students that most of what they learn in law school is useless for the practice of law."20

Failure to adopt as broad a curriculum base as possible, and settling on merely one pattern of teaching, proves stultifying for student motivation and morale. ${ }^{21}$ In such an environment, long before students leave law school, boredom has taken a strangle hold. ${ }^{22}$ The effect of such a limited vision can be not only debilitating but fraught with hidden dangers.

[Casebook education] imprisons the student [and] communicates 
messages about what is and is not important: judicial decisions are more important than statutes; adjudication is more important than other modes of law- making or conflict resolution; and adversary litigation is more important than advising, counselling, planning, drafting, and all the other things lawyers do. Student objectives become limited ... ${ }^{23}$

Exposure to a rigourous field placement may facilitate the fateful decision students must make concerning whether or not to practice law, and if so in what area. ${ }^{24}$

The literature on clinical education invariably stresses the values of reflection and generalisation, but student-centred learning may well be the primary goal of a clinical experience.

The student in an externship engages in a process of self-learning, based upon a construct which includes an evaluative relationship between supervisor ... and student. Students must "learn how to learn” from experience ... The job of law schools, and of clinical training in particular, is to teach students how to self-learn and be self-critical. That is the essence of professional growth... . When [the placement is] properly structured, the student will both receive and provide more oneto-one feedback and evaluation on lawyering, teaching and learning than anywhere else in law school. ${ }^{25}$

An effectively established externship is an ideal setting for transforming students from their role as passive receptors of information into active learners, keen to recognise the nuances of professional responsibility. ${ }^{26}$ On a more mundane level, it also may simply satisfy the educational objective of teaching how the legal system works, ${ }^{27}$ a feat rarely achieved by the traditional curricula strategies. - In any live-client setting, there routinely arises a goalconflict between the education of the student and the service to the client. It has been suggested that rather than seek to resolve this conflict, it is preferable merely to acknowledge and live with the requisite tension. ${ }^{28}$ Such frictions are fundamental in legal education ("the tension between those who view law schools as part of the university's scholarly community and those who see them as training grounds for new lawyers"29). Securing at the outset a detailed structure for the placements goes some way to addressing this dilemma. ${ }^{30}$

\section{MODES OF IMPLEMENTATION}

\section{Specialist}

Possible sites to be considered for an externship program are 
with specialist agencies related in some way to a particular course in the curriculum. For example, a course in Criminal Procedure may settle on something like the Office of the Director of Public Prosecutions as a site for student placement. Similarly, an agency akin to the Environmental Defenders Office may be a valuable placement venue for students in an advanced Environmental Law course. Connections between members of Faculty and various external bodies (eg the Public Interest Advocacy Centre) may generate sufficient interest in contacts to motivate parties towards the establishment of a placement program with that agency Organisations such as, inter alia, the Trade Practices Commission, the Director of Public Prosecutions, the Legal Aid Commission, the Australian Tax Office, the Human Rights and Equal Opportunity Commission may be suitable largely because of their connections with various Faculty members, and their connections with courses run by the law school. Courses which may be perceived as obvious candidates for placement consideration include Criminal Law, Immigration, Family, Constitutional, Taxation, Trade Practices, Human Rights - the list is only limited by lack of imagination. It is important to recognise that these specialist placements may be as much an opportunity for general policy and law reform work as for traditional lawyering.

A placement with a firm of solicitors which practices solely in one area of law might also be considered as a suitable venue for a "specialist" externship program, especially where that single area of law has its obvious parallel in a course taught in the law school. Factors such as the weight to be given to public service ideals may need to be addressed in influencing a decision relating to the appropriateness of such a placement.

\section{General Practice}

A placement with a firm engaged in general practice need not be linked in any definite way with a course in the law school curriculum. The emphasis in this case is more on educating students as to "how the law works". Thus matters such as legal practice skills, professional responsibility and legal ethics become the primary focus, with substantive matters taking a secondary role. Questions relating to site supervision, Faculty input, and educational ideals need to be fully canvassed and communicated to 
ensure that the scourge/myth of the student photocopier does not become the reality.

Once again, some connection between the firm and a Faculty member may be the initial stimulus towards establishing the placement. This may be the area in which the law school determines to transform an existing summer clerkship program into something more educationally oriented and clinically inspired. Methods which were originally employed to inaugurate and enhance a summer clerkship program should be reharnessed. Summer clerkships remain one of the most valuable sources of future employees for the participating firms. Their commitment to the transformation proposed here should be even stronger, given the ultimate benefits to themselves, the students and the law school.

\section{Judicial Clerkship}

One further method of providing students with a clinical experience is to establish a program of supervised judicial clerkships. There can be (and is) a broad spectrum of applications of judicial externships: on one level, students acting as genuine clerks (even writing draft opinions); on the other, performing no task beyond mere observation of the court process. The latter application would not satisfy generally accepted definitions of “clinical experience”, lacking fundamental ingredients such as "active participation" and "interaction in role". ${ }^{31}$ In the more authentic portrayal of a clerkship, the student simply assumes and performs a recognised role within the legal system. That role experience then becomes the focal point for intellectual inquiry. ${ }^{32}$

Law schools which already have contact with the judiciary through post-degree judge's associates appointments, need to develop these connections more fully in an endeavour to establish a program of judicial externships.

A detailed examination of a conventional clerkship program was provided by the analysis of the Judicial Intern Clinic at William Mitchell College of Law. ${ }^{33}$ The clinic's professed goal was "a greater understanding of the judicial system and its role in dispute resolution in our society". Students were to be involved in the whole proceedings of a jury trial, from the time of jury selection until verdict. Students also were to be exposed to most other judicial processes. ${ }^{34}$ The sole prerequisite for enrolment in the 
clinic was to complete the course Professional Responsibility.

The Intern Clinic class would meet four or five times during the semester, at the first of which was a discussion of the ethical responsibilities of judges' clerks. Reading materials were nominated, and the vexed question of confidentiality would be stressed; resolving the confidentiality dilemma remained the primary concern of potential judicial participants. ${ }^{35}$

Once a student was assigned by Faculty to a particular judge, all relevant parties would meet to ensure that each of the participants understood their respective responsibilities. The judge would be required to permit the student to be involved in the above-stated activities, and at the conclusion of the placement would submit an evaluation form to assist grading. The student was obliged to produce at least one major written project of the judge's choosing, although usually many more assignments would be requested. Students also had to keep a detailed daily diary of their observations, as well as a monthly report on work undertaken for submission to the judge. The remainder of the Intern Clinic classes would involve a thorough analysis of the legal and para-legal issues arising out of the student's experiences with the judge. A personal interview between the student and the instructor would occur midsemester to review written work and assess the value of the educational experience.

\section{CONSIDERATIONS REGARDING IMPLEMENTATION}

As emphasised already, mere work experience is not sufficient. ${ }^{36}$

So long as the critical role of practice-based learning is allowed to remain invisible and unplanned, the learning that comes out of this relationship will be ad hoc and capricious. ${ }^{37}$

Proper planning is crucial to the future educational veracity of an externship program. Adequate supervision on site, as well as by a member of Faculty, is a considerable commitment, as is the notion of a beneficial classroom component. These will be addressed below.

It is recommended that these further steps be undertaken to ensure a fulfilling endeavour: ${ }^{38}$

(a) The law school can make enrolment in the placement 
conditional on the completion of certain specified courses relevant to the work to be undertaken. Co-requisites subjects to be taken during the course of the externship may also be useful stipulations. (The classroom component to the placement is different again.)

(b) The law school should exercise care over the selection of placements. With the educational value to the student being paramount, the range of learning experiences coupled with the quality of guaranteed supervision should be the significant determining factors.

(c) The law school may wish to cultivate a more structured method of student reflection by the implementation of student journal requirements. These may be general observational jottings, or detailed experiential answers to specific questions. Coupled with complex assignments, these materials can be periodically reviewed by Faculty to gauge the effectiveness of the student's reflective capabilities.

(d) The law school can monitor the time spent by students on the various tasks engaged in during the placement by requiring that time and activity reports be lodged and signed. Negative (or positive) trends regarding supervision, responsibility and so on can be readily evaluated, assisting not only the present student but any potential externs as well.

(e) The law school might investigate the possibility of producing a range of externship program materials, outlining the course structure and the parties' responsibilities. These may also include supervisor training manuals.

\section{Supervision on Site}

Because students are no longer under the immediate, fulltime direction of Faculty, quality supervision at the placement is crucial to the educational worth of the externship program. The on-site "service v. education" conflict may result in a variety of unsatisfactory scenarios: ${ }^{39}$ externship sites participating in the placement program merely to obtain free labour (for example, for photocopying); the pressures of practice meaning little or no time for the students; supervisors lacking the requisite skills of supervision; ${ }^{40}$ dearth of critique of the legal system emanating from narrow perspectives of supervisors; students encountering only part 
of a case, without gaining a rounded understanding of the whole legal process.

These problems are not easily overcome. Some commentators have suggested that rather than find ways to improve supervision, educators should find ways to manage without it. ${ }^{41}$ That solution/dilemma aside, remedies have been promoted by a few commentators to address the problem of inadequately trained supervisors. The most common approach adopted by North American law schools has been to ignore the predicament. Recent results from a survey have been quite revealing:

Field supervisors, and the offices and agencies for which they work, are provided little or no financial support by the law schools, no training in clinical teaching, and no status within the academic community. They are, however, assigned virtually all of the clinical teaching responsibility. ${ }^{42}$

This is coupled with the fact that although externships are at least as prevalent as in-house programs, and student enrolments in placements are substantially higher than in in-house programs, the resources, financial and personnel, devoted to externships by law schools is negligible. ${ }^{43}$

Familiarity with, and acceptance of, the Faculty's educational goals for its students is a fundamental first step, often and easily overlooked. Negotiated written agreements are sometimes entered into, detailing the educational objectives of the placement, the responsibilities of the supervisor towards the student with respect to supervision and evaluation, as well as the student's role and obligations during the externship. ${ }^{44}$ (For instance, at California Western School of Law, the form cataloguing students' lawyering tasks is termed an Experience Check List.) Detailed written evaluation forms for each participating party in the placement program have also been adopted. ${ }^{45}$

The experience of the Semester in Practice Program at Vermont Law School is enlightening when considering what sort of training should be administered to potential supervisors. ${ }^{46}$ Practical applications have shown that if the field supervisor has the requisite qualities, that person's role as "mentor” to the student can prove to be a remarkably valuable one. ${ }^{47}$ Attorneys grow to respect their role as instructors with an eye to the future, in the same way that their counterparts in the medical field do so. 
Mentors appreciate the fact that in learning to supervise and teach law students, they are also learning to better train the new attorneys or judicial clerks with whom they work. ${ }^{48}$

At Vermont, each potential mentor must have legal expertise. But they must also exhibit "the desire to teach and the time to do it."49 Mentor training focusses on the art of effective critique, perceived to be the capability most wanting. Adult learning theory, or the realisation that people learn differently, is impressed upon the mentors, as is the understanding and adoption of the notion of learning types via the Myers-Briggs Type Indicator. ${ }^{50}$ The training then progresses to unearthing the skill of performance evaluation through the concept of feedback. ${ }^{51}$ Matters learnt are reinforced by the insistence that two or more people from the same placement site should attend (to ensure mutual reinforcement in the office setting), and by a process of follow-ups by the Faculty representative in person and on the telephone. The pivotal foundation of the training program is planning. ${ }^{52}$ Only by careful planning can proper evaluation of the success (or otherwise) of the externship take place. That process of monitoring is crucial.

It has been suggested that law schools should consider offering site supervisors compensation, as an inducement to participate, or as a reward for having done so.

Compensation would provide the law school with increased accountability from site supervisors to ensure that students receive adequate supervision. ${ }^{53}$

These surrogate intimidations aside, the key to meaningful cooperation surely lies with effective collaboration. Including site supervisors in the planning and adjudication process would provide them with a properly identifiable role, rather than the shadowy persona to which they are customarily abandoned. Outright refusal to do this, as has been the norm in recent times, risks perpetuating the disinterested, disorganised nature of so many externship programs.

But the critical failing of the law school system of designing fieldwork curricula ... is that it totally excludes field placement personnel from meaningful participation in the process... . It is essential, therefore, that a decision-making structure be created for the design and oversight of externship programs that includes representatives from the field on an equal basis... . The critical point is that the makeup of this decisionmaking body, and the formal allocation of authority, will then be shared by the law school rather than monopolised. Sharing responsibility in 
this way should alleviate much of the basic structural problem of externships. $^{54}$

Whether law schools would be prepared to acquiesce in such a solution, or dismiss it as a derogation of their educational responsibilities remains to be seen. ${ }^{55}$ One would have to recommend that law schools seriously considered the dual prerequisites of co-operation and collaboration as outlined above.

The account of the operation of the Internship Program at California Western School of Law provides useful insight into the focus accorded site supervision during the course of a placement. ${ }^{56}$ Potential site supervisors attend the Supervising Attorneys Training Program, a workshop designed, through discussion and role play, to bolster the quality of supervision furnished by the attorneys. To help monitor progress, communication between the attorneys and Faculty continues throughout the program.

With regard to the training of students in lawyering skills, the supervisor must act as a guide, not merely as a saviour with answers at the ready. The supervisor must be prepared to expose the student to as broad a variety of challenges as possible, and discuss fully the implications of each step in the legal process. Imparting a sense of professional responsibility is rudimentary.

Both by serving as a role model and by engaging in dialogue with the student, the supervising attorney is the most influential teacher of professional responsibility. ${ }^{57}$

The task is hampered by the fad that so much of what the attorney does must come as second nature, but may require to be articulated for the student's benefit. So too must supervisors be prepared to provide students with positive feedback, to facilitate the development of the students' capacities to learn from their experience. $^{58}$ It is not too idealistic to imagine that in such a process of evaluation and re-evaluation, an externship may provide a rich source of continuing education for the attorneys who act as mentors.

\section{Supervision by Faculty}

The problem of students gaining unstructured work experience devoid of Faculty guidance has already been touched upon. ${ }^{59}$ Externship programs, at least in theory, present law schools with an 
opportunity to exert some influence over that learning potential. It is apparent, however, that in North American law schools, Faculty involvement in placement programs is "spotty and irregular". 60 Once again, co-operation and collaboration in the planning of a structured placement program is the key. The question of incorporating a classroom component into the externship program will be discussed below.

Some law schools would perceive the supervisory role of Faculty to be principally a monitoring one. At California Western, ${ }^{61}$ for example, this may take the form of ensuring that all participants are aware of their respective obligations, and overseeing that these commitments are being met. Memoranda of Agreement, and Experience Check Lists help everyone to be more fully cognisant. The Faculty member may also act as a troubleshooter, anticipating or thwarting communication breakdowns, and addressing work complaints if and when they arise. Meetings with the various parties may thus aid the smooth functioning of the program. The meeting with the student may even become a client interview "role play". Review of work performance through discussions and the assessment of written work, ${ }^{62}$ reinforces the notion of professional competency expected of the intern. The journal requirements imposed by Faculty supervisors are not necessarily documents to be shared with site supervisors.

Similarly, the Faculty member should be striving to stimulate an intelligible critique of the legal system, ${ }^{63}$ especially where client pressures may impinge upon the site supervisor's best intentions. Being "at least a step removed", the Faculty member can offer a different perspective. ${ }^{64}$ Important too is the inspiration to be given by further encouraging the student's self-directed learning - the passive student metamorphosing into the active, enquiring "junior" professional. To be fully aware of potential ethical obstacles, the Faculty member would need to be reasonably well versed in legal practice and its professional rules. The job requires a teacher who has practiced law and who can relate with students when they discuss their experiences in the field. Finally' the person must be a good listener ... and enjoy working with attorneys. ${ }^{65}$

It is self-evident that the Faculty member responsible for coordinating and supervising must have experience in the practice of law. 
Where Faculty supervision is viewed not only as a valuable ingredient, but as essential to the educational integrity of the externship program, the law school will be at pains to promote its enterprise.

The clinical director ... visits each placement as often as possible during the semester, to observe and review the students' placement activities. During those visits, the clinical director also meets with supervisors, to emphasize that the law school values the supervisor's effort and is serious about participating in quality clinical legal education. The program fosters its concern by involving field supervisors in the educational process outside the placement and by communicating its expectations to field supervisors. Hopefully, this ongoing communication between the law school and field placement supervisors sensitizes supervisors to the educational mission of the school of law and results in a higher quality of field supervision. ${ }^{66}$

Another important advantage not always fully appreciated is that "client confidences will be better protected if faculty members are one step removed from the process of client representation." 67 So too will harmony between site supervisors and faculty. Where that aura of detachment is not present, problems regarding the division of responsibility materialise. What is the proper role of the Faculty member supervising the student's work?

Where [externships] do not confine the professor to consideration of the "long view", and he or she begins to question and intervene in decisions made in connection with the case work, the tension that is inherent in a system that subjects students to two quite different supervisors will begin to surface. ${ }^{68}$

An exceptionally skilled diplomat would be required to overcome such an intolerable situation. The only realistic solution would appear to be Faculty exclusion from such confidential dealings. Prior planning and agreement should guarantee that these dilemmas do not emerge. ${ }^{69}$

The subject of resources needs to be addressed, but no easy answer is necessarily forthcoming. Some commentators believe regular visitations to be out of the question.

The resource implications of this level of supervision, where a tutor may have to visit each student on a regular basis, are such as to militate against the employment of this particular method on a large scale. ${ }^{70}$

Certainly the demands on the Faculty member would be severe enough without having to frequent placement sites. ${ }^{71}$ The odd visit, coupled with pre-planned arrangements regarding on-site 
supervision and externship classes (both group and private) should prove a sufficient Faculty contribution. There must be a consequent teaching load recognition for placement supervision and monitoring.

\section{Externship Class}

Another illustration of effective Faculty input into the externship experience is the co-requisite of a classroom component. Where no prerequisites are stipulated for students before enrolling in the placement program, the classroom component is frequently employed as a base for skills instruction, or else as an opportunity to undertake in-depth substantive study in a specialised area being covered in the placement. Where prerequisites deal with these matters specifically, the class, if nothing more, is a structured opportunity for group reflective discussion — to analyse what has been witnessed.

But, it is not enough to let students see these things. Mere exposure may breed cynicism, despair or disgust. It is essential to give students perspective on what they see: the causes of the problem; what is being done about it; the special responsibilities of the legal profession, if any, in the area. Thus, a strong classroom element should accompany any fieldwork experience. ${ }^{72}$

But because of the nature and variety of externships, any notion of "structure" must permit of a fair degree of flexibility. As has been recognised, "sensitivity to what the students need to enhance their field experience is essential”. ${ }^{73}$

Externship classes undeniably have their imperfections. One not easily addressed is the fact of remoteness: that the teacher holds classes dealing with the fieldwork, but the teacher is not actually in the field. ${ }^{74}$ The fact that the Faculty member may visit the student at the placement, perhaps on more than a couple of occasions, does not really overcome the problem. The maintenance of journals (which have been studied by the clinician) detailing placement experiences can be a valuable source of material for discourse in class. Otherwise, the query remains of how to make the material covered in class relevant to the externships. This may be exacerbated by the fact that the placements in any one program may actually be at a significantly diverse range of venues.

Placements suffer from basic inequalities in experience and a difficulty 
in relating the experience to the aims of a particular course? ${ }^{75}$

One possible way of countering this complication is by "dividing the students into groups with common experiences (ie, all students in criminal practice settings, or all students working with judges)". ${ }^{76}$ This has the disadvantage of losing the shared experiences of group discussions, where the very diversity of the settings is the enhancement.

Student resistance to a classroom component is another problem likely to be encountered, as has been the case at California Western. ${ }^{77}$ Having their impatience to practice satisfied by the externship experience, they then resent the return to the classroom; the need for reflection and generalisation are not goals readily accepted by the students. Careful preparation of course materials and imaginative implementation is required to deal with the hurdle - a balance of group meetings and personal interviews is an obvious preliminary measure.

At Catholic University, ${ }^{78}$ the primary goal of the externship class is to foster professional development: assisting students to make informed career choices. Coupled with this is the aim to empower students to secure for themselves a valuable field experience: to procure quality supervision, feedback and assignments. Students receive extensive counselling and advice regarding placement selection, and are encouraged to choose an institutional setting unfamiliar to them (and one not within the sphere of their summer clerkships). Specific, prearranged topics are discussed in class, with flexibility to delve into other matters as they arise. Visiting attorneys and judges elaborate on problem areas. $^{79}$ Class discussion focusses on supervision and critique: students are encouraged to shape their own field experience. The group discussion is seen as advantageous in that the student receives in-depth exposure to one placement setting, as well as cursory exposure to numerous other experiences. ${ }^{80}$

Similarly, at Boston College Law School, ${ }^{81}$ one focus is on encouraging students to learn "how to be supervised: students actually interview prospective site supervisors and choose one. (Obviously, if things are not progressing as hoped, the students themselves should be in the position to complain; the Faculty member supervising the placement in a monitoring capacity is the 
person to decide whether the placement should continue, for that student as well as for the future. ${ }^{82}$ ) There is lengthy discussion on how students can best identify and realise their learning goals, and on how to master experiential learning. Case studies on the social responsibility of lawyers is a crucial component of class discussions; ethical dilemmas from readings and those encountered on site are the principal sources. A generalised goal therefore, would be a better understanding of the workings of the legal system.

\section{Assessment}

Without structured supervision, both on site and from Faculty, and a co-requisite of a classroom component to instigate reflection and self-directed learning, there seems little reason to grant students academic credit for their "work experience". Where those essential conditions are satisfied, there seems no logical reason not to grant adequate credit, although there are still vocal detractors. ${ }^{83}$ One commentator has revealed how illogical is the North American position:

[L]ife experience credit is available towards a liberal arts degree for demonstrated ability, work experience, and technical training obtained outside of school but is not available towards a degree in law school, where one might expect demonstrable increases in professional competence to be more highly valued than they would be in a liberal arts degree. $^{84}$

Put simply, to deny credit to a properly structured externship program is to deny the intrinsic value of a clinical education experience.

If true co-operation and collaboration exists between the site supervisors and Faculty members, then the assessment of students should be by Faculty in consultation with those site supervisors. ${ }^{85}$ Whether or not the credit granted should be graded would seem to depend on just how closely the student's day-to-day performance is monitored by Faculty. At California Western for example, one unit of the course receives a numerical grade, with the remainder a pass/fail. The numerical grade is based on the journals and written assignments, as well as contributions in discussions. 


\section{Expense}

An actual breakdown of expenditure for externship programs has never been systematically undertaken - what information there is available is cursory. Although admittedly out of date, figures (from 1980) quoted by one commentator prove to be very enlightening.

An article published ... as a Consultant's Report suggested that the median cost per student credit hour was $\$ 510.00$ for in-house programs and $\$ 40.00$ for externships. ${ }^{86}$ The greater the Faculty involvement in the externships, the greater the cost of running the program. But specific figures to which any meaning might be attached are elusive. A study of clinical education in Florida failed to provide concrete answers, merely that externships are considerably less expensive than in-house programs. ${ }^{87}$ Figures will be influenced by the numbers of Faculty involved, their reduction in other teaching commitments and the numbers of support staff involved.

\section{Student Time}

At the Judicial Intern Clinic at William Mitchell, ${ }^{88}$ the student undertook the course for either two or four credits, resulting in a time commitment of between 96 and 192 hours. The understanding was that the student would "honour" that commitment, without an actual tab being kept, unless of course, in the eyes of the judge, there was a blatant discrepancy. In a judicial clerkship, it seems highly unlikely that work hours would be problematic.

Other commentators have emphasised the advantages in students compiling comprehensive time records. ${ }^{89}$ For example, in the Litigation Skills Program at the University of Miami, ${ }^{90}$ detailed, weekly time and activity reports must be completed by the student and approved by the supervising attorney. The information provided is analysed by the training director and the Faculty supervisor to oversee that the necessary educational challenges are being offered and met, and to ensure that any problems can be quickly addressed.

Whether the placement is a whole semester commitment, or some percentage thereof, is another consideration requiring careful assessment. The externship may be only a minor part of a course, or virtually the entire program (and not merely in terms of the time component). The variables are such that no concrete figures can be 
spelt out here.

\section{Administrative Support}

The establishment and operation of an externship program requires a considerable and committed support component from administrative staff. The actual personnel involved depends on the size of the program: numbers of students, variety of site placements, whether the externship Director has other teaching commitments. Assisting in the preparation of course materials for the classroom component is a further, though commonplace, burden. The primary role of administrative staff would be in supporting the Director's function as monitor of the externship program (eg corresponding by letter and telephone to assist in the arrangement of meetings and so forth).

\section{EXAMPLES}

\section{In the United States}

Contrary to claims that clinical education is somehow on the wane, ${ }^{91}$ statistics (and first-hand observation) reveal that clinical programs are healthily growing throughout the United States. In a recent compilation of data on law Schools, ${ }^{92}$ but one of the 175 ABA-approved law schools reported detailed clinical offerings, ${ }^{93}$ and a majority of these schools include placement programs in their list of clinical options. ${ }^{94}$ Externships which have stimulated commentary in journal articles are mentioned below.

\section{University of Minnesota Law School}

At Minnesota Law School, ${ }^{95}$ externship programs (the Domestic Abuse Clinic and the Public Interest Law Clinic are two examples) have been developed which incorporate a classroom component as well as joint responsibility for case supervision. In the latter clinic, externship classes are taken by the clinical faculty once a week. Work during placements must comply with the educational goals as stipulated by the Faculty, and students' written work is reviewed by the clinical faculty, 


\section{University of Miami School of Law}

At Miami Law School, ${ }^{96}$ their clinical placement program is well entrenched. The school claims that supervision has been maximised and its educational goals made attainable. Students must attend at placement for at least 220 hours per semester, whilst also satisfying the remainder of their course requirements. Placement supervision is thorough. Following consultation with Faculty, students are allocated by the training director (who is a senior staff attorney) to departments within the agency, to work directly under an attorney. All progress is closely monitored through the training director. As already mentioned, ${ }^{97}$ time and activity reports assist effective monitoring of the program.

One of their placement venues warrants special mention.

The Dade County state attorney's and public defender's offices ... offer students opportunities which would be difficult to match even at great cost. These offices are organised into what are in effect "minilaw firms", with the same attorneys practicing before the same judges for weeks or months at a time. The intern enters as a junior member of the "firm", and learns to practice before the judge through ongoing observation and supervision. Because the same judge and lawyers observe the intern's work on a regular basis, they can accurately evaluate and bring about improvements in quality over time. The repetitious nature of the work allows the intern to increase skills and competence, and the volume of work provides an opportunity for substantial trial practice. The intern progresses from simple to more complex tasks, and may move from misdemeanour or juvenile cases to felony cases over the course of the program. ${ }^{98}$

If the Faculty involvement in planning and structuring of the placement accords with the principles already outlined, the externship appears to be a remarkably valuable one. No mention is made of a classroom component however, and its absence would surely be a significant gap in the educational potential of the program. As always, there needs to be that distancing, that other perspective which an experienced Faculty clinician could offer. The opportunity for reflection and the encouragement of self-directed learning must materialise, else there has not been a true clinical experience.

\section{California Western School of Law}

The Internship Program at California Western, although already touched upon, warrants further mention. Students are placed with 
sole practitioners or large firms, with public interest organisations or with members of the judiciary. Work is carried out under the supervision of the attorney or judge, whilst selection of the placements and overall supervision of the site participants - the monitoring function - rests with the clinical faculty. Students work between 12 and 40 hours per week, depending on the number of units undertaken. Before the commencement of the placement, there is an orientation session with the clinical faculty, in which course requirements are thoroughly evaluated. Further pre-arranged classes (individual and group sessions) occur throughout the duration of the placement. Students must maintain journals for experiential reflection, time and activity reports, and produce work for Faculty evaluation. A personal placement evaluation must also be completed at the conclusion of the externship. The site supervisor must complete two student evaluations - a brief midsemester one and a more complex one at the end of the placement. Site supervisors undergo a period of supervision training under the guidance of the clinical faculty. On agreeing to participate in the placement program, the site supervisors must sign a Memorandum of Agreement, acknowledging their supervisory roles and accepting the educational requirements of the law school.

\section{In Canada}

The following examples are gleaned from Goldring's study ${ }^{99}$ of the implementation of "clinic" in Canadian law schools. University of Toronto Completion of a prerequisite, Canadian Constitutional Law, entitled 20 students to enrol in the Constitutional Litigation Program, a two semester course (one-fifth of the year's workload) of which the initial fourteen weeks were standard seminars emphasising procedural aspects. Thereafter, the students were placed with practitioners renowned for their skill in constitutional litigation. ${ }^{100}$ There was no remuneration either for work performed by the student or for supervision by the practitioner. Projects to be undertaken were approved of in advance, although efforts would be made to satisfy the students' fields of interest. Close contact with the site participants was maintained by the Director, whose workload of co-ordination and supervision was considerable. Course objectives were listed as including "the obtaining of a sound grasp of technical rules of law relating to constitutional 
procedure and an appreciation of the process of litigation on constitutional law". 101

\section{Osgoode Hall Law School, York University}

Quite apart from their clinical connection with the famed Parkdale Law Centre, Osgoode Hall offers a variety of clinical programs.

- Intensive Program in Criminal Law: available to 20 students selected by ballot. The prerequisites of this one semester (full workload, 15 credits) course are Criminal Law, Criminal Procedure and Evidence. The course was comprised of three sections: firstly, two weeks of all-day intensive classes intended to hone skills in negotiation, interviewing, cross-examination and sentence addresses; video-taped court room simulation exercises for in-depth analysis and performance criticism, and drafting exercises. A classroom component of 1-2 days a week would continue for the entire semester (with a significant emphasis on role play). Secondly, a placement with Crown or defence counsel, or with a judge, for ten weeks (3-4 days a week). The complementary classroom component "is really an advanced course in Criminal Procedure which draws on the work which the students are doing in the course of their placement". ${ }^{102}$ The students worked on assigned cases under the supervision of their site mentors and were to keep detailed diaries for weekly assessment by the course Director. The Director would keep in close contact with the site supervisors, and stress student reflection at all times. Thirdly, an intensive two week course review, with visiting experts to expand horizons.

- Intensive Program in Immigration and Refugee Law: a recent addition to the curriculum, it blends seminars with placements and supervised research. The course splits into three components: the Law of Admission to Canada, the Law of Exclusion from Canada, and the Law of Refugee Protection.

Within each module, students are placed for a two-week period in a relevant externship in either an advocacy, bureaucratic, or adjudicative setting. Because the geographical settings within which immigration and refugee law work occurs are a substantial determinant of policy perspectives and outcomes, students are placed across Canada and in embassies and international 
organizations in other countries. ${ }^{103}$

- After each placement is a series of in-house simulation exercises, and at the conclusion of the course is an intensive research and writing exercise, all attempting a "melding of doctrine, theory and hands-on experience”.

\section{University of Calgary ${ }^{104}$}

Calgary introduced an innovative though controversial curriculum after the establishment of its law school in $1975 .{ }^{105}$ Coupled with traditional law subjects throughout the curriculum are courses with a more "practical” leaning: courses which include the formulation of submissions to the legislators, courses involving trial advocacy and civil procedure, skills workshops emphasising interviewing, negotiation and counselling. In the final semester, students enrolled in one of four "practicum" courses (their full workload for the semester). For present purposes, the three of them which included placements warrant noting. In each case, the course Director was a person with considerable practice experience and a network of contacts.

- Resources Practicum: prerequisites of Administrative Law and Property Law, and a co-requisite of Advanced Oil and Gas Law. The climax of a very demanding and complex course (simulations, seminars, skills training, lengthy research project) was a two week placement, personally chosen by the course Director, "with an energy tribunal, a government department, a public interest centre such as the Environmental Centre in Edmonton and occasionally with law firms [or] with the legal department of oil and gas corporations”. ${ }^{106}$ The placement work and supervision was thoroughly arranged between the site supervisor and the course Director. The need for student reflection was emphasised, and written reports demanded of students (re their work experience) and supervisors (re student performance). Funds set aside for the practicum were to be used to assist students placed out of Calgary. Student reaction to the practicum ranged from its being too arduous, to its being lightweight.

- Family Law Practicum: aimed at the integration of theory and practice. Although Family Law was not a prerequisite, its completion was desirable. Students were required to submit a 
major (supervised) research paper, as well as present reports on the placement and keep detailed diaries for review by fellow students and the Director. Placements, closely monitored at all times by the Director, would commence with an agency working in the family law area, progress to a placement with duty counsel in the juvenile division of the provincial court, and conclude with a placement with a family law practitioner. Evening seminars would be given by experts on the various topics. The placement with the duty counsel would "involve the students working on three to five cases selected with the intention of giving the students experience in a variety of types of legal work including drafting, counselling, negotiating, advocacy in court and general advice". ${ }^{107}$ As well as assisting the Director with review of written work, two part-time clinical instructors would accompany students during court appearances (as required under Alberta law). Students responded very favourably to the practicum.

- Criminal Law Practicum: was further evidence of the integration of theory with practice. Students were placed with prosecution or defence counsel personally chosen by the Director. Details of work to be undertaken and of supervision were conveyed to the site supervisors who were expected to adhere to the directives. There was also a classroom component involving in-depth seminars (from visiting experts as well as the Director), and students were to write the usual research reports and diaries. Again student response tended to be favourable.

\section{In Britain}

Brunel University: the "sandwich approach The law course at Brunel has a very strong "business" orientation, as well as including the study of courses from other Social Sciences departments (eg economics, sociology and government). Brunel is reputed to have the highest percentage of graduates finding employment in law-related work of any English law school. Brunel has adopted the "sandwich approach in the formulation of its curriculum, as it aims to offer students practical experience to complement academic studies. ${ }^{108}$ By graduation, students have accumulated 60 weeks work experience. Brunel views what it offers to its students pragmatically: 
The idea behind the Integrated (Sandwich) degree is to combine the study of principles with experience and practice. Each helps the other: knowledge of the Law equips you to work in the Law, and experience of practical realities helps you to understand legal principles... . Above all you can gain the experience that will give you the edge over other graduates competing for the best jobs. ${ }^{109}$

With an undergraduate intake of 40 per year (plus 15 per year for the Business and Finance Law degree), implementation of its educational goals is decidedly feasible.

The students embark upon a compulsory 20 week placement (for which they receive remuneration) in each of the first 3 years of the course, leaving the final year solely to academic pursuits. At the conclusion of each placement, students complete a pre-planned project. In the first 2 years the project is simply an un-graded report on the placement; the third year project is crucial: it is a comprehensive, analytical dissertation (10,000-15,000 words) which is graded. Each student is assessed on his or her performance during the placement — the whole placement amounting to onefifth of the final degree marks. In the event that the student's work is deemed unsatisfactory (eg the student may have been dismissed) they must undertake another placement. The experience gained in the placement can count towards articles.

The Work Placement Officer ${ }^{110}$ organises the establishment of the placement. The suitability of potential employers is based on criteria such as range of work offered, facilities available and supervisory experience. Students are placed after interviews with the employers. Students are assigned a placement tutor who visits twice during the placement and liaises with the employer as well to ensure that progress is satisfactory. The tutor may seek to pre-plan the work to be undertaken during the placement. Communication and feedback between the participators is encouraged: students must immediately complain if matters of significant concern arise. A mid-June tutorial day endeavours to integrate students back into the university.

Students must be placed in legally-related work (eg solicitors, legal departments of commercial companies, government departments, magistrates). Most students undertake three different placements, although some might be placed at the same site for three years. A common example would be a first year with a magistrate or Crown prosecutor, a second year with a firm of 
solicitors, perhaps specialising, and a third year with a different firm, or a legal aid office. The placement is partly arranged on the basis of the individual student's choice, although mainly governed by availability.

It is unquestionably true that Brunel's sandwich offering does not satisfy generally accepted notions of clinical legal education. Faculty involvement is cursory, and there is certainly not a complementary series of on-campus seminars during the course, partly because of the resource implications with students placed nationwide. Given its educational goals, Brunel may simply not view them as necessary. Furthermore, supervision on site does not appear to be the fulfilment of Faculty dictates regarding educational objectives. Faculty contact with the student is more in the nature of a debriefing than comprehensive critiques and reflections. But there is contact with the student whilst at the placement, there are project requirements to be satisfied, monitoring does occur with the assistance of detailed response forms. So it would not be fair simply to dismiss the program as unstructured work experience devoid of Faculty guidance ${ }^{111}$ — after all, it is leagues ahead of any summer clerkship program presently in operation.

One could argue a case for adopting a revised form of this model fashioned so as to satisfy clinical aspirations. With a more organised structure built into the placement program, ensuring more systematised supervision on site, more educationally constructive contact between the Faculty and the placement participants, and a classroom component to critique and develop self-directed learning, the students would be parties to a valuable clinical experience. One would have to recommend that, at the very least, serious consideration be given to developing such a program in the ways already outlined.

\section{CONCLUSION}

To end, I shall be brief. It has not been my intention to salute externships as the be all and end all of applications of clinical legal education. For the purists, the live-client clinic is still the pinnacle towards which all those truly enamoured with clinical education should be striving. This article is merely a plea to practicalities. In times of recession, the resources may simply not be available to establish and effectively maintain a fully-functional clinic. Live- 
client clinics demand money, they demand dedicated and gifted individuals working long hours under considerable strain. And in most cases they benefit only a small percentage of the overall student population. In contrast, externships can be much less demanding on all levels. (Notwithstanding that apparent attraction, as has already been indicated, a well-structured externship program makes considerable demands on its participants.)

Most law schools have some structure of summer clerkships available to a vast majority of their students - as a basis on which to build. With the networking framework, however rickety, already in place, the task of formulating a beneficial program of field placements can begin. The crucial questions concerning the adequacy of supervision and the intensity of critique must be satisfied else the exercise will frustrate strictly clinical ideals. But, as one writer has neatly reasoned, the effort needs to be made.

Both theory and practice in legal education are sterile if divorced from each other. The intellectual process of connecting theory and practice must be a major focus of legal education. ${ }^{112}$

The obstacles to be confronted are not insurmountable, but as I have attempted to demonstrate, they are substantial.

* Sydney University Law School. I would like to express my thanks to Simon Rice, and James Crawford for their encouragement. This article is based on writings for a forthcoming (DEET-funded) Report on Clinical Legal Education, and the views expressed have been influenced by, and are geared towards, that Report.

(C) 1993. (1993) 4 Legal Educ Rev, 29.

1 See M Stickgold, Exploring the Invisible Curriculum: Clinical Field Work in American Law Schools (1989) 19 New Mexico Law Review 287, at 298.

2 If one assumes that an effective placement model demands the regular visitation by the Faculty member to the student on-site, thus introducing complex resource implications, then the veracity of this conclusion is brought into question: see A Boone, M Jeeves \& J MacFarlane, A Working Model for Clinical Legal Education: Testing the Definition Against a Range of Examples (1987) 21 Law Teacher 172, at 175.

3 ST Maher, The Praise of Folly: A Defense of Practice Supervision in Clinical Legal Education (1990) 69 Nebraska Law Review 537, at 544. See also at 571 11107: "[Externships] can offer a wide variety of litigation and non-litigation opportunities to students in many different areas, and at a modest cost to the school, when compared with the cost of other clinical programs.”

4 H Rose, Legal Externships: Can They Be Valuable Clinical Experiences for Law Students? (1987) 12 NW L Rev 95, at 96.

5 Maher, supra note 3, at 540.

6 The highly structured and manufactured nature of simulations is also seen as a weakness because of the consequent restrictions on the development of studentcentred learning, which is acknowledged as a primary goal of clinical legal education: see Maher, supra note 3, at 564. See also AL Spitzer, Clinical 
Education in Florida (1988) 12 Nova L Rev, 797, at 801: "What is missing from simulation courses is the excitement and motivation of representing live clients, a stimulus which heightens commitment and learning by the student.” And see SF Befort, Musings on a Clinic Report: A Selective Agenda for Clinical Legal Education in the 1990s (1991) 75 Minn L Rev 619, at 628 n40: “Although simulation courses are excellent vehicles for lawyering skill instruction, they are less capable of replicating the dynamics of the lawyer/client relationship than clinics with real clients and real cases.”

7 Stickgold, supra note 1, at 291. See also DJ DeBenedictis, Learning By Doing: The Clinical Skills Movement Comes of Age (1990) (September) 76 ABAJ 54, at 59, and Spitzer, supra note 6, at 800: “[M] ost law professors involved in externship programs admit to some level of slippage between aspiration and performance."

8 J Motley, Self-Directed Learning and the Out-of-House Placement (1989) 19 New Mexico L Rev 211, at 226.

9 "Most other professional curricula long ago incorporated field placement experiential learning as integral parts of the educational plan. Many have fieldbased learning at the core of the curriculum, and course-work is built around it.": see Stickgold, supra note 1 , at 314 .

10 "At least fifty percent of medical instruction is clinical education, a figure light years beyond the minuscule credit hours that law students are permitted, but not generally required, to devote to clinical experience.”: see RC Cramton, Professional Education in Medicine and Law: Structural Differences, Common Failings, Possible Opportunities (1986) 34 Cleveland State L Rev 349, at 352.

11 "The challenge is not to find ways to eliminate part-time work, but to find ways to make such work even more beneficial to students. ... [T] solution to this problem is to integrate off-campus work into the law school curriculum [via an externship program].”: see Maher, supra note 3, at 395-6.

Stickgold, supra note 1 , at 315 .

13 Motley, supra note 8, at 222-224. See also Maher, supra note 3, at 589: “The diversity [externships] provide enhances the total law school program.”

14 "The placements [at Nova University] include legal aid agencies, municipal and county attorney's offices, state agencies such as the Attorney General's office and the comptroller and the departments of labor and transportation, and federal agencies such as the Securities and Exchange Commission and the Internal Revenue Service.”: see R Braccialarghe, H Messing and WE Adams Jr, Having It All — Offering Criminal and Civil Inhouse and Extern Programs (1991) 65 Florida Bar J (July/August) 39. Placements also occur with government agencies "whose responsibilities included legislative, administrative or judicial reform ... A sample of such placements included the offices of U.S. Senators or members of Congress, federal and state legislative committees, federal administrative agencies, including the N.L.R.B., the S.E.C., the F.C.C., and F.C.T., the National Merit System Protection Board, state supreme courts and judicial councils, Federal District and Circuit Courts of Appeal, and agencies of the United Nations, and other international agencies.”: Stickgold, supra note 1, at 316 111-13.

15 "[California Western] has placed students in offices where they may learn the practice of patent law, medical malpractice, construction defects, real estate law, corporate law, education law, banking law, international law [as well as] numerous opportunities to work within the court systems in judicial internships.”: Motley, supra note 8, at 222.

16 Stickgold, supra note 1, at 318. For an interesting comparative discussion, see FS Bloch and IS Ishar, Legal Aid, Public Service and Clinical Legal Education: Future Directions From India and the United States (1990) 12 Michigan Journal Int'l Law 92.

17 Maher, supra note 3, at 547-548. 
HR Sacks, Student Fieldwork as a Technique in Educating Law Students in Professional Responsibility (1968) $20 \mathrm{~J}$ Legal Educ 291, at 294.

19 See Boone, Jeeves \& MacFarlane, supra note 2, at 173: "Placing a student in a 'work environment' is not sufficient. To be clinical, a work experience must allow active first-hand engagement in the role of 'worker', with responsibilities and decisions falling on the student.”

Stickgold, supra note 1, at 316.

Cramton, supra note 10 , at 353 . Without the imaginative innovation, what has been likened to a "malaise" sets in: "Our students learn to play the Socratic game well in the first year. Thereafter they want a change; they want to begin to apply their skills in new and challenging ways. Their level of motivation rises considerably when at last they can perform in professional contexts.”: see AC Aman, Studying Music, Learning Law: A Musical Perspective on Clinical Legal Education (1987) 13 Cornell LF 8.

22 "Students clerk primarily because they are bored with law school. ... [B]oredom is a significant and constant problem, particularly in the third year.”: see Maher, supra note 3, at 595 (and references to Frankfurter and others at n 191).

Cramton, supra note 10 , at 354 .

24 Motley, supra note 8, at 223.

25 Stickgold, supra note 1, at 317. See also Maher, supra note 3, at 566: "Encouraging students to take more responsibility for their own learning and providing students with an opportunity to develop better evaluative skills are common educational objectives of practice supervised placements." See also Motley, supra note 8, at 220: "The primary purpose of clinical courses ... is to develop students' ability to learn from their experience.”

26 "It is difficult to conceive of a more fertile environment for law students to examine their own emerging conceptions of professional role than in clinical placements that involve the representation of clients under the supervision of experienced attorneys." See Rose, supra note 4, at 99. See also Motley, supra note 8, at 221 and Aman, supra note 20, at 12 .

Maher, supra note 3, at 568.

28 Maher, supra note 3, at 585. See also Motley, supra note 8, at 319 and Rose, supra note 4, at 104.

29 JO Mudd, Beyond Rationalism: Performance-Referenced Legal Education (1986) 36 J Legal Educ 189 at 191.

30 "Each law school should explicitly define the educational objectives that it seeks to achieve through its externship program .... . The actual structure of the externship program should be dictated by the program's objectives.” See Rose, supra note 4, at 106.

31 "[C]linical education may ... be defined as a curriculum-based learning experience, requiring students in role, interacting with others in role, to take responsibility for the resolution of a potentially dynamic problem.” See A Boone, M Jeeves LJ MacFarlane, Clinical Anatomy: Towards a Working Definition of Clinical Legal Education (1987) 21 LMU Teacher 61, at 68.

32 Note discussion by Smith (University of Utah), Tape 19: Judicial Externships, AALS Conference on Clinical Legal Education, 2-6 January 1991, Washington D.C.

33 DF Herr, Supervised Judicial Clerkships: A Valuable Clinical Experience (1983) 9 William Mitchell L Rev, 151. As of late 1990 (at least), the clinic was alive and well.

34 "[Also] students are expected to observe a wide variety of judicial activity, including criminal appearances, arraignments, pleas and sentencings, presentations of civil pretrial motions, pretrial conferences and settlement conferences, and chamber conferences between the judge and the judge's fulltime law clerks. Students participate in discussions of the judge's opinions and 
help prepare drafts of bench memoranda or opinions.” See Herr; supra note 33, at 153.

For a rigorous evaluation of the confidentiality obstacle, see Maher, supra note 3 , at 555. Judges may demand either the exclusion of Faculty involvement from review of the student's work, or else limited appraisal of specified work. The key to the riddle lies, as always, with prior contemplation and agreement.

"[A]lthough any experience has the potential for teaching lessons, most people will only maximise the value of that experience through subsequent structured reflection, which is difficult enough to ensure within a formal curriculum and impossible outside it.”: see Boone, Jeeves \& MacFarlane, supra note 2, at 1767, referring to KR Kreiling Clinical Education and Lawyer Competency: The Process of Learning to Learn From Experience Through Properly Structured Clinical Supervision (1981) 40 Maryland L Rev 284.

M Meltsner, Healing the Breach: Harmonising Legal Practice and Education (1986) 11 Vermont L Rev 377, at 385. Insufficient planning has "resulted in training by osmosis rather than by design”: see Rose, supra note 4, at 104 .

See, for example, Maher, supra note 3, at 598-605.

39 See, for example, Rose, supra note 4, at 104.

40 See Motley, supra note 8, at 226.

41 Maher, supra note 3, at 578 (quoting Professor Amsterdam n137).

42 Stickgold, supra note 1 , at 313.

43 Stickgold, supra note 1, at 312-313.

44 See Maher, supra note 3, at 605, Rose, supra note 4, at 107, and Motley, supra note 8 , at 220,225.

45 See Motley, supra note 8, at 213, 225. Copies of these forms are held by the author.

46 See L Cole, Training the Mentor: Improving the Ability of Legal Experts to Teach Students and New Lawyers (1989) 19 New Mexico L Rev 163. My thanks are due to Professor Cole for providing me with detailed documentation regarding their programs.

47 Stickgold, supra note 1, at 318. In Greek mythology, when Odysseus embarked for the Trojan War, he delegated his affairs, and especially the care of his son Telemachus, to his dependable friend Mentor. The term mentor has embraced the notions of trusted adviser and guardian. For a discussion of the process of grooming a mentor, see Cole, supra note 46.

48 See Cole, supra note 46, at 164 n7. See also Rose, supra note 4, at 111: "In the medical profession, experienced physicians value opportunities to train medical students and impart their knowledge and insight about practicing medicine. The same should be true of practicing attorneys."

49 See Cole, supra note 46, at 165. Put simply, site supervisors must "have a strong commitment to training law students”: see Rose, supra note 4, at 106. For a similar attitude adopted at California Western, see also Motley, supra note 8, at 214: "The supervising attorney's primary motivation for participating in the program must be an educational one." (original italicised)

50 For a detailed analysis, see I Briggs Myers \& PB Myers, Gifts Differing (1980), and D Peters and MM Peters, Maybe That's Why I Do That: Psychological Type Theory, the Myers-Briggs Type Indicator, and Learning Legal Interviewing (1990) 35 New York Law School L Rev 169. Another example is the Kolb Learning Style Inventory which is employed at California Western School of Law. See Motley, supra note 8, at 220-1. Also note discussion Tape 23: Students Who Learn Differently: Stories and Strategies, AALS Conference on Clinical Legal Education, 2-6 January 1991, Washington D.C. For discussions of further applications of the Myers-Briggs Type Indicator, see D Peters, Learning Low-Visibility Lawyering Skills at the Virgil Hawkins Civil Clinic (1991) (July/August) 65 Florida Bar Journal 45, at 48; and see 
DeBenedictis, supra note 7, at 55 (for a discussion of its application at the University of Hawaii).

51 See Cole, supra note 46, at 1689 . The simplistic formula is: firstly to describe the activity the student is engaged upon; secondly to interpret that activity; thirdly to verbalise one's feelings about the activity; fourthly to proffer a recommendation for appropriate change.

52 The Semester in Practice Program at Vermont Law School resorts to Kreiling, supra note 36, as its stimulus for discussion.

53 See Rose, supra note 4, at 106. See similarly Stickgold, supra note 1, at 326, and Maher, supra note 3 , at 605 , where the author raises the possibility of conferring the title of "adjunct professor" as an inducement.

54 See Stickgold, s u p note 1, at 321-2. On the strength of the results of the survey undertaken by the author, he was able to conclude (at 313) that "[f]ield supervisors and students, the two primary players in the fieldwork clinical program, appear to have little, if any, role in the design, approval or selection of the various placement programs, or of the classroom component when one accompanies the placement”. The author proceeds (at 323-6) to elucidate his plans for the formal division of responsibility with regards to teaching and supervision.

55 Externships have been rejected by Stetson University because "it is believed that such programs generally improperly relieve the law school of its obligation to provide for the educational development of its students by transferring that responsibility to the agency”: see JC Latimer, Clinical Programs - Pioneering, Innovative, and Effective (1991) 65 Florida Bar J (July/August) 43. Their views on collaboration may be interesting.

See Motley, supra note 8, at 214-222.

57 See Motley, supra note 8, at 218.

58 See Motley, supra note 8, at 220.

59 See text accompanying footnotes 11 and 12. See also Boone, Jeeves \& MacFarlane, supra note 31, at 68: "[A] planned curriculum model will provide the opportunity for reflection and analysis, whereas extra-curricula activities do not necessarily include a formal mechanism for the evaluation of learning."

60 See Stickgold, supra note 1, at 313.

61 See Motley, supra note 8, at 216ff. The author notes (at 227) that without Faculty involvement, "[t]here would be no way to know just what attitudes and skills our students are learning and no way to ensure the continued quality of the placement”.

62 See Maher, supra note 3, at 603; and Boone, Jeeves \& MacFarlane, supra note 2, at 175 .

63 "[F]aculty supervisors should encourage students to be reflective about their own performance as lawyers, about the outcomes the legal system produces, and about the way their experiences are influencing their professional and personal sensibilities.”: see Rose, supra note 4, at 109.

See Motley, supra note 8, at 218. See also Rose, supra note 4, at 105: “A valuable component of a clinical experience is providing students with a theoretical framework for understanding the lawyering process and allowing them to contrast theoretical considerations with their actual practice experiences."

65 See Motley, supra note 8, at 228-9.

66 See LD Pertnoy, 'Clinic' is Not a Duty Word (1991) 65 Florida Bar / (July/August) 41, describing clinical implementations at St. Thomas University. For a similar depiction of externships at Florida State University, see C Gregg, Tallahassee Offers Rich Variety of Opportunities (1991) 65 Florida Bar J (July/August) 37.

67 See Rose, supra note 4, at 108. 
See Maher, supra note 3, at 552. See the same author's piece Clinical Legal Education - Past, Present and Future (1991) July/August) 65 Florida Bar Journal 28, at 35. See also RJ Condlin, 'Tastes Great, Less Filling': The Law School Clinic and Political Critique (1986) $36 \mathrm{~J}$ Legal Educ 45, at 70: "The clinician must... recognize that his task is not to pass judgment on attorney work ... The professor is engaged in studying the profession, not grading it." (sexism in the original) See footnote 35 and accompanying text re judicial clerkships. See Boone, Jeeves \& MacFarlane, supra note 2, at 175.

"Direct supervision of student field work and daily supervisor performance is just inappropriate for law school faculty in the externship model.”: see Stickgold, supra note 1, at 326-7.

See Sacks, supra note 18, at 294. See also Maher, supra note 3, at 600, and Rose, supra note 4, at 108: "[T] he role of the faculty supervisors should focus on assisting students to identify the deeper legal, professional, institutional, and personal lessons about the lawyering process that the externship offers."

See Maher, supra note 3, at 601.

See discussion by Lerman (Catholic University), Tape 25: The Externship Seminar, AALS Conference on Clinical Legal Education, 2-6 January 1991, Washington D.C.

See Boone, Jeeves \& MacFarlane, supra note 2, at 175. See also Motley, supra note 8, at 227: "Where 25-60 students are each doing very different work, it is difficult to create a relevant classroom component for all of them."

See Rose, supra note 4, at 109.

See Motley, supra note 8, at 227-8.

See Lerman, supra note 74.

So too at St Thomas University. "Topics include motion practice, discovery, plea bargaining, trial simulations, ethics, predicates for the introduction of evidence": see Pertnoy, supra note 66, at 42.

See also Motley, supra note 8, at 228, where the author summarises the benefits of group discussions.

See discussion by Liebman (Boston College), supra note 74 .

See Maher, supra note 3, at 586-7.

See PG Haskell, Legal Education Can Be Cheaper, Quicker and Better (1971) 22 Case Western Reserve L Rev 515, at 517: "Sending students out to a legal aid office to do routine chores and report back to a faculty member periodically may add to the students' personal growth ... but it is not within the definition of education for academic credit."

See Maher, supra note 3, at 592.

See Rose, supra note 4, at 110.

See Maher, supra note 3, at 640.

See Spitzer, supra note 6, at 804-7.

See Herr, supra note 33, and accompanying text.

See Rose, supra note 4, at 110 . Not only does it verify work practices from the educational viewpoint, it assists students to develop law office skills for future practice.

See LM Rose, The Litigation Skills Program — An Integrated Approach (1991) (July /August) 65 Florida Bar J 50, at 51.

See DR Nolan, The Status of American Legal Education (1989) 1 Legal Education Rev 183, at 199-202.

2 G Munneke ed, Barron's Guide to Law Schools, 9th ed, (1990). See also discussion by McDermott (West Virginia), Tape 20: In-House Clinics, AALS Conference on Clinical Legal Education, 2-6 January 1991, Washington D.C. 
The odd one out was George Mason University School of Law in Virginia, which prides itself in its adherence to the case method.

94 Innovative programs are not simply the domain of the smaller, trendier law schools. Columbia Law School "offers internships in community development, housing law, prisoners' rights, immigration, public-interest advocacy, child advocacy, law and the arts, and race and property law. Additional training is available through arrangements with Morningside Heights Legal Services, city agencies, consumer advocacy groups, and clerkships with Criminal, Family, and Federal Court judges". Harvard Law School provides "students with field work in local courts and government agencies... . Field placements are available in business law, civil and criminal law, mediation, and environmental law". (There are countless other clinical programs as well.) Stanford Law School's "externship program allows students to spend a semester away from campus, during the second or third year, in carefully supervised practicums for which academic credit is available. Examples include work with public interest law organisations, local district attorney and public defender offices, trial and appellate court clerkships, assistantships in comparative law institutes abroad, and staff assignments with administrative agencies and legislative committees": see Munneke, supra note 92, at pp141, 165, and 217 (for Columbia, Harvard and Stanford respectively).

See Befort, supra note 6, at 628.

96 See Rose, supra note 90. The Litigation Skills Program is a merger of a variety of offerings. "Students may now choose to pursue one or more of a multisemester sequence of courses that provide intensive training, beginning with demonstrations and simulations critiqued by an established faculty of attorneys and judges and progressing toward either an advanced simulation course or supervised externship.": see Rose, at 50.

97 See supra note 90, and accompanying text.

98 Rose, supra note 90 , at 50.

99 J Goldring Learning Law in Action (1986) Unpublished, School of Law, Macquarie University.

100 The course Director had a vast network of contacts, from whom were chosen only those practitioners personally respected for their expertise. My thanks are due to the former course Director, Professor Sharpe, for his correspondence.

101 See Goldring, supra note 99, at p34.

102 See Goldring, supra note 99, at 36. The course, which has been in successful operation for 16 years, is very much alive and well as of February 1992. My thanks are due to the course Director, Professor Grant, for his helpful correspondence.

103 See Osgoode Hall Law School Calendar 1990-91, at 48.

104 Detailed documentation is held by the author. My thanks are due to Dr Sheilah Martin and Ms Joy Bowes of the Law Faculty at Calgary for their assistance.

105 For a discussion of the considerable problems encountered, see ME Hughes, Law Faculty Developments at Calgary, 1984-1989 (1990) 13 Dalhousie LJ 778.

106 See Goldring, supra note 99, at 40.

107 See Goldring, supra note 99, at 44.

108 The new law degree at the University of New England (Northern Rivers) at Lismore will embrace the sandwich approach and anticipates incorporating up to twelve months of non-compulsory placements into its structured three year graduate program. The role of the Faculty will be to facilitate the attainment of employment simply by this compilation of a register of prospective placement sights. At this stage there are no proposals for compulsory, supervised externships (nor any of the ensuing dilemmas). My thanks are due to Professor Jim Jackson for his informative comments. Although not directly relevant, mention should also be made of "The Professional Program" blueprint (May 
1992) of the Law Society of New South Wales. It envisages that, from 1994, students will be required to undertake, on completion of their academic studies, a course of practical training (of 12 weeks duration) followed by practical experience (for a period of 33 weeks) in order to satisfy admission requirements.

109 See Brunel University Undergraduate Courses Handbook, (March 1991), at 4. See also the analysis by M Partington, Academic and Practical Legal Education: The Contribution of the 'Sandwich' Course (1984) 2 J Prof Legal Educ 27.

110 The information was obtained during an informative interview at Brunel with the Work Placement Officer, Donna Cody, August 1991.

111 See supra notes 11,12,19 and 59, and the accompanying text.

112 See EM Schneider, Integration of Professional Skills into the Law School Curriculum: Where We've Been and Where We're Going (1989) 19 New Mexico L Rev 111, at 112 .

* Before going to press, I received detailed documentation from the Dean of the new Faculty of Law at the University of Newcastle, Professor Neil Rees, concerning their Bachelor of Laws course beginning in 1993. It appears to be a particularly thorough attempt to integrate theory and practice. Clinical elements infuse most traditional compulsory subjects, whilst the clinical stream subjects will embark on a rigorous deployment of simulation exercises and placements. The utilisation of legal office placement has been stipulated for the following subjects: Torts, Commercial Law, Family Law and Practice, Revenue Law, Wills and the Administration of Estates, Conveyancing, and Commercial Law II. "[The] placements ... will be organised, supervised and assessed by the Director of Clinical Education [an academic at the Associate Professorship level] and members of staff with clinical appointments": see the University of Newcastle Faculty of Law, Application for Accreditation, 28 August 1992, at 8. The nature and extent of placement implementation awaits to be seen. 